\title{
Use of aminated hulls of sunflower seeds for the removal of anionic dyes from aqueous solutions
}

\author{
T. Jóźwiak ${ }^{1}$ - U. Filipkowska' $\cdot$ S. Brym² $\cdot$ L. Kopeć ${ }^{1}$
}

Received: 25 April 2019 / Revised: 2 September 2019 / Accepted: 9 September 2019 / Published online: 17 September 2019

(c) The Author(s) 2019

\begin{abstract}
In this study, we analyzed the effectiveness of sorption of dyes popular in the textile industry (Reactive Black 5, Reactive Yellow 84, Acid Yellow 23, and Acid Red 18) on aminated and non-aminated seed hulls of common sunflower (Helianthus апnии $L$.). The scope of the study included: determination of the effect of $\mathrm{pH}$ on dye sorption effectiveness, sorption kinetics analyses (sorption equilibrium time, pseudo-first-order/pseudo-second-order model, intramolecular diffusion model), and determination of the maximum sorption capacity against dyes (Langmuir/Freundlich isotherm). The sorbent was subjected to the FTIR analysis. The sorption capacity of the aminated sunflower seed hulls against reactive dyes RB5 and RY84 accounted for $51.02 \mathrm{mg} / \mathrm{g}$ and $63.27 \mathrm{mg} / \mathrm{g}$, respectively, and was higher by $1665 \%$ (17.6 times higher) and $1425 \%$ (15.3 times higher) compared to that of non-modified hulls. In the case of acidic dyes, Acid Yellow 23 and Acid Red 18, the sorption capacity of the aminated sunflower seed hulls reached $44.78 \mathrm{mg} / \mathrm{g}$ and $42.19 \mathrm{mg} / \mathrm{g}$, respectively, and was higher by $1881 \%$ (19.8 times higher) and 2284\% (23.8 times higher), respectively, compared to the non-modified hulls.
\end{abstract}

Keywords Amination $\cdot$ Anionic dyes $\cdot$ Sorption $\cdot$ Sunflower seeds hulls

\section{Introduction}

Dyes are compounds which bind permanently with different materials or substances, thereby imparting color to them. The greatest demand for colorants comes from the textile, tanning and paper industries (Okoniewska 2016). Over 100,000 dyes of various types are available on the market and their global production accounts for over $800,000 \mathrm{Mg}$ (Revankar and Lele 2007). Today, anionic dyes represent the largest group of produced dyes (Papić et al. 2004).

Editorial responsibility: M. Abbaspour.

Electronic supplementary material The online version of this article (https://doi.org/10.1007/s13762-019-02536-8) contains supplementary material, which is available to authorized users.

T. Jóźwiak

tomasz.jozwiak@uwm.edu.pl

1 Department of Environmental Engineering, University of Warmia and Mazury in Olsztyn, ul. Warszawska 117a, 10-957 Olsztyn, Poland

2 Chair of Relativistic Physics, University of Warmia and Mazury in Olsztyn, ul. Słoneczna 54, 10-710 Olsztyn, Poland
Anionic dyes dissociate in water, and this reaction results in the formation of a color anion. They are mainly used for dyeing fibers with a base character like wool or polyamide fibers. Owing to their very good solubility in water and often low affinity to the material being dyed, even up to $50 \%$ of the anionic dyes used in this process are discarded with postproduction wastewater (Lewis 1999). For this reason, these dyes are considered the most important and the most common type of contamination of colored industrial wastewater.

Dyes present in industrial wastewater are a highly hazardous form of contaminants. Their penetration into the natural environment may trigger severe changes in the water ecosystem. For example, anionic dyes may reduce the access to light for autotrophs in natural aquifers even at the concentration of $1.0 \mathrm{mg} / \mathrm{L}$. This may result in the inhibition of photosynthesis and death of part of the higher plants. The presence of dyes in water may also contribute to reduced oxygen diffusion in water which together with photosynthesis decay may lead to the development of anaerobic conditions in water and, consequently, to the collapse of the aquatic ecosystem. In addition, many types of dyes and products of their degradation may be toxic to aquatic fauna (Crini 2006). 
Considering the widely understood welfare of the aquatic environment, it seems advisable to use the most effective methods of wastewater decolorization. Systems for dyes removal from wastewater should be developed especially as intended for the removal of anionic dyes because they are the most frequent component of colored industrial wastewater.

Adsorption is commonly believed to be one of the best methods for dyes removal from wastewater. In the case of dyes, this process consists in the accumulation of color substances on the whole available surface of the adsorbent. Both Van der Waals forces, as well as hydrogen, ionic and covalent links may be involved in the process of dye binding on the sorbent. An advantage of adsorption is its low cost resulting mainly from sorbent price. Its effectiveness depends on sorbent type and conditions of the sorption process $(\mathrm{pH}$, temperature, stirring rate, ionic strength) (Gupta and Suhas 2009).

Very good capability for anionic dyes sorption is exhibited by chitosan which in this case outclasses even activated carbon. Chitosan sorption capacity against selected anionic dyes may exceed 1000 mg/g (Jóźwiak et al. 2015, 2017b). The high efficiency of chitosan as a sorbent results from the presence of secondary amine groups in its structure, which are responsible for its base character. Capable of protonation $-\mathrm{NH}_{2}$ groups of chitosan are the main active center against anionic dyes (Annadurai et al. 2008). Unfortunately, the amount of available raw material for the production of chitosan sorbents has recently depleted on the market as chitin and chitosan are purchased by pharmaceutical companies for the production of glucosamine. In view of the curbed access to chitosan, a search is underway for its cheaper substitutes.

A polysaccharide whose chemical structure resembles that of chitosan is cellulose (Fig. 1). As the main constituent of cell walls of higher plants and also of some algae and bacteria, cellulose is the most widespread biopolymer worldwide. The difference between the presented polysaccharides results from the presence of a primary amine group in chitosan at the site of the hydroxyl group of cellulose.

Increased interest has recently been observed in the use of high-cellulose waste materials from the agri-food industry for wastewater treatment. Significant advantages of such sorbents include their very low price and very high availability. Ample studies have been investigated the possibility of wastewater decolorization using high-polysaccharide waste materials. The lignocellulose waste sorbents investigated so far have included, among others: stems of crops (Tunç et al. 2009), skins of citrus fruits (Arami et al. 2005; Mafra et al. 2013), potato skins (Tiwari et al. 2015; Lairini et al. 2017), sawdust (Dulman and Cucu-Man 2009; Ratnamala et al. 2016), nutshells (Ponnusamy and Subramaniam 2013) and pumpkin seed hulls (Çelekli et al. 2014). Despite a high content of polysaccharides, with structure similar to that of chitosan, they failed to achieve dye sorption capacity comparable to that of chitosan sorbents. The low effectiveness of dye sorption onto biosorbents rich in cellulose and hemicellulose is most likely due to the neutral character of these

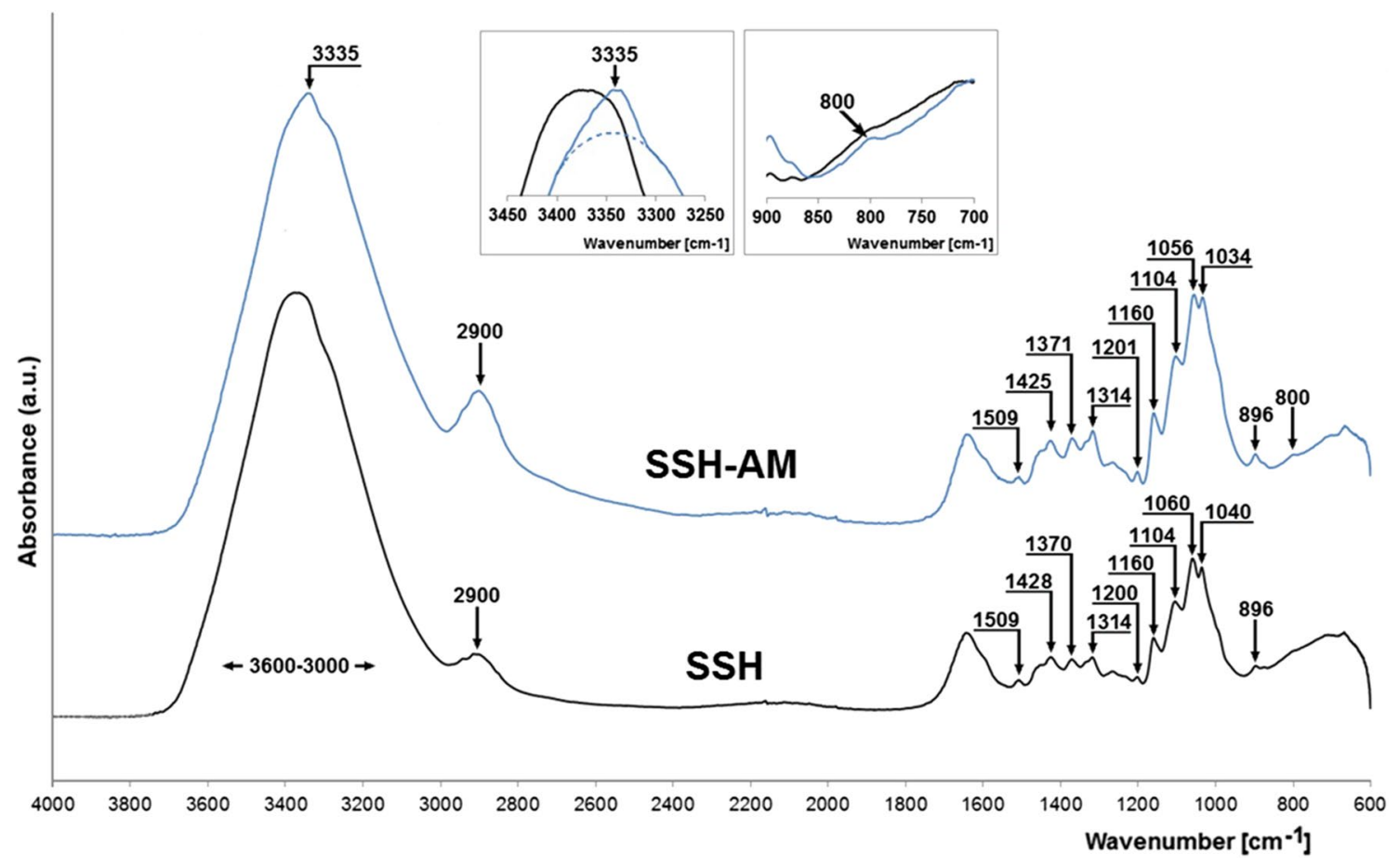

Fig. 1 IR spectra of SSH and SSH-AM 
polysaccharides, and to a lack of functional groups capable of easy protonation.

An idea has emerged, therefore, to increase sorption capabilities of polysaccharide sorbents through enrichment of their polysaccharides with amine functional groups. It was assumed that after attaching the amine group to the polysaccharide chain, the polysaccharides having the neutral character (like cellulose) would attain base character and sorption properties similar to that of chitosan.

A functional amine group may be inserted into the structure of an organic molecule via the amination process. The amination of a substance proceeds as a result of contact with an aminating agent. Popular aminating agents include, among others: ethylenediamine, triethylenetetramine and melamine. Organic compounds may also be aminated via ammonization, i.e., reaction with ammonia.

Amination of polysaccharides is often preceded by polysaccharide activation with epichlorohydrin which enriches the material in epoxide groups that easily attach amines via addition (Liu et al. 2013; Razavi and Akhlaghinia 2015; Abdollah et al. 2014).

The objective of this study was to determine the possibility of increasing sorption capabilities of a lignocellulosic waste material against anionic dyes as a result of ammonization (amination with ammonia water) process. Sunflower seed hulls (with $\sim 90 \%$ content of polysaccharides and lignins) were used as the sorbent, the sorption capabilities of which were tested against anionic dyes popular in the textile industry, including two reactive dyes (Reactive Black 5, Reactive Yellow 84) and two acidic dyes (Acid Yellow 23 and Acid Red 18). Research to the article was conducted at the Department of Environmental Engineering of the University of Warmia and Mazury in Olsztyn (Warszawska 117a, 10-720 Olsztyn, Poland) and lasted from April to June 2017.

\section{Materials and methods}

\section{Sunflower seed hulls}

The study was conducted with seed hulls of sunflower (Helianthus annuus L.) collected at an agri-farm in Poland. Contents of individual polysaccharides in the hulls are as follows: cellulose-42.7\%, hemicellulose-24.0\% and lignin-23.2\% (Saura-Calixto et al. 1983).

\section{Dyes}

The study was conducted with anionic dyes popular in the textile industry including two reactive dyes: Reactive Black 5 (RB5) and Reactive Yellow 84 (RY84) and two acidic dyes: Acid Yellow 23 (AY23) and Acid Red 18 (AR18). Dyes originated from a dye production plant Boruta-Zachem SA in Bydgoszcz, Poland; their characteristics are presented in Table 1.

\section{Chemical reagents}

The following chemical reagents were used in analyses:

- Epichlorohydrin > 99\% (ACROS ORGANICS, Poland),

Table 1 Characteristics of dyes used in the study

$\begin{array}{ll}\text { Dye name } & \text { Reactive Black 5 } \\ \text { Structural formula }\end{array}$


- Hydrochloric acid 35-37\% a.p. (POCH S.A., Poland),

- Sulfuric acid $2 \mathrm{M}$ solved solution (POCH S.A., Poland),

- Sodium hydroxide a.p. (POCH S.A., Poland).

\section{Laboratory equipment}

The following laboratory equipment was used in the study:

- HI $110 \mathrm{pH}$ meter, HANNA Instruments, Poland.

- Basic Shaker SK-71, JEIO TECH, Korea.

- Water bath shaker type 357, Elpin-Plus, Poland.

- Multi-Channel Stirrer MS-53M, JEIO TECH, Korea.

- UV-3100 PC spectrophotometer, VWR spectrophotometers, Canada.

- Nicolet 6700 FTIR spectrometer with a single-reflection diamond ATR element, ThermoElectron Scientific, USA.

\section{Preparation of sunflower seed hulls (SSH)}

Sunflower seed hulls were rinsed with water, dried and disintegrated in an electric laboratory grinder. The disintegrated bulk of hulls was sieved through a laboratory screen with a mesh diameter of $4 \mathrm{~mm}$. The sunflower seed hull fraction which passed through the 4-mm screen was next sieved through a laboratory screen with a mesh diameter of $2 \mathrm{~mm}$. The fraction of hulls left on the 2-mm screen, i.e., hull particles with diameters of 2-4 $\mathrm{mm}$, was used for analyses.

After disintegration and sieving through screens (fraction of 2-4 mm), the hulls of sunflower seeds were immersed in $2 \mathrm{M}$ sulfuric acid $\left(\mathrm{H}_{2} \mathrm{SO}_{4}\right)$. After 24-h contact with the acid, the hulls were drained and rinsed with distilled water. Next, they were immersed in sodium hydroxide $(\mathrm{NaOH})$ for another $24 \mathrm{~h}$. Afterward, the hulls were drained and rinsed with distilled water to remove $\mathrm{NaOH}$ residues. Ready for analyses hulls were stored in distilled water at a temperature of $4{ }^{\circ} \mathrm{C}$.

\section{Preparation of aminated sunflower seed hulls (SSH-AM)}

Amination of sunflower seed hulls was preceded by sorbent activation in the solution of epichlorohydrin.

Sunflower seed hulls (100 g d.m.) were weighed into a 300-mL conical flask, and a solution of epichlorohydrin (>99\%) was added. Next, the flask was put on a shaker with a water bath set at $100 \mathrm{rpm}$. stirring rate and a temperature of $60{ }^{\circ} \mathrm{C}$. After $24 \mathrm{~h}$, the hulls were drained and rinsed with distilled water to remove residues of non-reacted epichlorohydrin. Afterward, they were transferred to a conical flask $(300 \mathrm{~mL})$, to which $100 \mathrm{~mL}$ of ammonia water $(25 \%)$ were added. The flask was protected with foil and put on a shaker (100 rpm.) that was placed under a fume hood. After $24 \mathrm{~h}$, the hulls were drained and rinsed with distilled water. As in the case of the non-modified hulls, the aminated hulls were stored in distilled water at a temperature of $4{ }^{\circ} \mathrm{C}$.

\section{Determination of the effect of $\mathrm{pH}$ on dye sorption effectiveness}

Portions of sunflower seed hulls $(0.5 \mathrm{~g}$ d.m. each) were weighed into conical flasks $(250 \mathrm{~mL})$. Then, $100 \mathrm{~mL}$ of a dye solution $(50 \mathrm{mg} / \mathrm{L})$ with $\mathrm{pH}$ from 2 to 11 were poured into each flask (correction of the $\mathrm{pH}$ with solutions of $\mathrm{HCl}$ and $\mathrm{NaOH}$ ). Next, the flasks were placed on a laboratory shaker (150 rpm.). After $2 \mathrm{~h}$ of shaking, $10 \mathrm{~mL}$ samples were collected from flasks for spectrophotometric determination of the concentration of dye left in the solution. If necessary (concentration of the dye above the range of the calibration curve), the solution was diluted with distilled water and the result was recalculated.

\section{Kinetic analyses of dye sorption onto SSH and SSH-AM}

Sunflower seed hulls ( $5 \mathrm{~g} \mathrm{~d}$.m.) were weighed into conical flasks $(1000 \mathrm{~mL})$, and then solutions of dyes with the optimal $\mathrm{pH}$ (determined in point "Effect of $\mathrm{pH}$ on dye sorption effectiveness") and with concentrations from 10 to $500 \mathrm{mg} / \mathrm{L}$ were added to the flasks. The flasks were placed on a multi-station magnetic stirrer (150 rpm.). Samples of solutions $(5 \mathrm{~mL})$ were collected from the flasks in specified time intervals: 0/5/10/20/30/45/60/120/180/240/300/360 mi $\mathrm{n}$, for spectrophotometric determination of the concentration of dye left in the solution.

\section{Analyses of sorption capacity of the tested sorbents}

Sunflower seed hulls $(0.5 \mathrm{~g}$ d.m. $)$ were weighed into a series of conical flasks $(250 \mathrm{~mL})$; then dye solutions with concentrations from 10 to $500 \mathrm{mg} / \mathrm{L}$ and $\mathrm{pH}$ value determined in point "Effect of $\mathrm{pH}$ on dye sorption effectiveness" (results) were added to the flasks, which were then placed on a shaker (150 rpm.). Once the sorption equilibrium had been reached (based on "Analyses of sorption kinetics" (results)), samples of solutions $(10 \mathrm{~mL})$ were collected from flasks for determination of the concentration of dye left in the solution.

\section{Computation methods}

The quantity of dye sorbed on the tested sorbents was computed based on formula 1 :

$q_{\mathrm{S}}=\left(\left(C_{0}-C_{\mathrm{S}}\right) * V\right) / m$

where $q_{\mathrm{S}}$-mass of dye sorbed under static conditions (mg/g d.m.), $C_{0}$-initial dye concentration $(\mathrm{mg} / \mathrm{L}), C_{\mathrm{S}}$-dye 
concentration after sorption $(\mathrm{mg} / \mathrm{L}), v$-solution volume (L), $m$-sorbent mass (g d.m.).

Kinetics of dye sorption on the tested sorbents was described using the pseudo-first-order (2) and the pseudosecond-order (3) models, and also via the intramolecular diffusion model (4) (determination of the amount and intensity of sorption stages).

$\mathrm{d} q / \mathrm{d} t=k_{1}\left(q_{\mathrm{e}}-q\right)$

$\mathrm{d} q / \mathrm{d} t=k_{2}\left(q_{\mathrm{e}}-q\right)^{2}$

$q=k_{d i} * t^{0} .5$

where $q$-momentary quantity of the sorbed dye $(\mathrm{mg} / \mathrm{g})$, $q_{\mathrm{e}}$ - equilibrium quantity of the sorbed dye ( $\left.\mathrm{mg} / \mathrm{g}\right), t$ tion time ( $\mathrm{min}), k_{1}$-constant in pseudo-first-order equation $(1 / \mathrm{min}), k_{2}$-constant in pseudo-second-order equation $(\mathrm{g} /$ $(\mathrm{mg} * \min ))$ and $k_{d i}$-adsorption rate constant in the intramolecular diffusion model $\left(\mathrm{mg} /\left(\mathrm{g}^{*} \min ^{0.5}\right)\right)$

Experimental results from sorption capacity analyses were described using two sorption isotherms: Langmuir isotherm (5) and Freundlich isotherm (6).

$q_{\mathrm{S}}=\left(q_{\max } * K_{\mathrm{C}} * C\right) /\left(1+K_{\mathrm{C}} * C\right)$

$q_{\mathrm{S}}=K * C^{n}$

where $q_{\mathrm{S}}$-mass of dye sorbed under static conditions (mg/g d.m.), $q_{\max }$-maximum sorption capacity in Langmuir equation (mg/g d.m.), $K_{\mathrm{C}}$-constants in Langmuir's equation $(\mathrm{L} / \mathrm{mg}), K$-constant of sorption equilibrium in Freundlich model, $n$-constant in Freundlich equation and $C$ - concentration of dye left in the solution $(\mathrm{mg} / \mathrm{L})$.

\section{Results and discussion}

\section{FTIR analysis of SSH and SSH-AM}

The FTIR spectrum of sunflower seed hulls was achieved using the Nicolet 6700 FTIR spectrometer with a singlereflection diamond ATR element, ThermoElectron Scientific, USA. Sample scanning range covered infrared with a wavelength range of $4000-600 \mathrm{~cm}^{-1}$, and the resolution of each spectrum was $1 \mathrm{~cm}^{-1}$.

The FTIR spectrum of SSH (Fig. 1) was typical of the cellulose-based sorbent. Distinct peaks at $1060 \mathrm{~cm}^{-1}$ (backbone vibrations of $\mathrm{C}-\mathrm{O}$ bond), $1160 \mathrm{~cm}^{-1}, 1200 \mathrm{~cm}^{-1}$ (symmetric and asymmetric stretching of $\mathrm{C}-\mathrm{O}-\mathrm{C}$ bond) and $1314 \mathrm{~cm}^{-1}$ (oscillatory vibrations of $-\mathrm{CH}_{2}-$ at $\mathrm{C} 6$ ) are indicative of saccharides presence in $\mathrm{SSH}$. The peak at $896 \mathrm{~cm}^{-1}$ signalizes vibration of $\mathrm{C}-\mathrm{H}$ bond which deforms the hydrocarbon ring, whereas peak at $1104 \mathrm{~cm}^{-1}$ indicates asymmetric stretching of the saccharide ring. In turn, a distinct peak at $1040 \mathrm{~cm}^{-1}$ may indicate ring and side group vibrations of $\mathrm{C}-\mathrm{C}, \mathrm{C}-\mathrm{OH}$ and $\mathrm{C}-\mathrm{H}$. The peak at $1370 \mathrm{~cm}^{-1}$ denotes $\mathrm{C}-\mathrm{H}$ stretching in the plane, whereas the peak at $2900 \mathrm{~cm}^{-1}$ - symmetric stretching of $\mathrm{C}-\mathrm{H}$ bond. Presumably, the peak at $1424 \mathrm{~cm}^{-1}$ signalizes vibrations of $\mathrm{H}-\mathrm{C}-\mathrm{H}$ and $\mathrm{O}-\mathrm{C}-\mathrm{H}$ bonds, and that at $1509 \mathrm{~cm}^{-1}$ indicates backbone vibration of $\mathrm{C}-\mathrm{C}$ bond (Fan et al. 2012).

The spectrum of SSH-AM (Fig. 1) shows a peak at $3335 \mathrm{~cm}^{-1}$ (bending of $\mathrm{N}-\mathrm{H}$ bond) within a wide range of $\mathrm{O}-\mathrm{H}$ vibrations $\left(3000-3600 \mathrm{~cm}^{-1}\right)$. The peak at $800 \mathrm{~cm}^{-1}$ indicates $\mathrm{N}-\mathrm{H}$ stretching out of plane. Peaks of the $\mathrm{N}-\mathrm{H}$ bond may indicate that amine groups were present and the amination process did proceed. The SSH-AM spectrum is also characterized by the shift of peaks from 1040 to $1034 \mathrm{~cm}^{-1}, 1060$ to $1056 \mathrm{~cm}^{-1}$ and 1424 to $1428 \mathrm{~cm}^{-1}$. Similar shifts of peaks were also observed in spectra of aminated pumpkin seeds (Subbaiah and Kim 2016).

\section{Effect of pH on dye sorption effectiveness}

Sorption effectiveness of anionic dyes onto SSH was the highest at $\mathrm{pH} 2$, and at the initial $\mathrm{pH}$ values of $\mathrm{pH} 2-5$ was decreasing along with $\mathrm{pH}$ increase (Fig. 2). At pH 5-9, the sorption effectiveness maintained at a similar, low level. In the case of reactive dyes (RB5/RY84), an insignificant increase was observed in their sorption effectiveness on $\mathrm{SSH}$ at pH 11 (Fig. 2a, b), whereas in the case of acidic dyes (AY23/AR18) the effectiveness of their sorption on SSH was the lowest at this pH (Fig. 2c, d).

The effectiveness of dye sorption onto aminated sunflower seed hulls (SSH-AM) at $\mathrm{pH}$ 3-11 decreased along with $\mathrm{pH}$ increase and reached the highest value at $\mathrm{pH} 3$ and the lowest one at pH 11 (Fig. 2). In the case of the reactive dyes, sorption effectiveness decrease along with $\mathrm{pH}$ increase was not uniform in the entire analyzed range of $\mathrm{pH}$ values. The decrease in sorption effectiveness of the reactive dyes on SSH-AM at pH 5-9 was relatively small compared to the acidic dyes.

The high effectiveness of anionic dyes removal on SSH at $\mathrm{pH} 2$ was, probably, due to the change in sorbent surface character at low $\mathrm{pH}$. Presumably, at $\mathrm{pH} 2$ the concentration of $\mathrm{H}_{3} \mathrm{O}^{+}$ions was high enough to induce protonation of the functional hydroxyl groups of polysaccharides present in hull structure. The positively charged surface of SSH was electrostatically attracting dyes having a negative charge in the solution. While at higher $\mathrm{pH}$, the number of protonated hydroxyl groups of SSH was significantly lower, which was reflected in a low intensity of anionic dyes sorption.

The ammonization process resulted in the amination of polysaccharides (e.g., cellulose/hemicellulose) occurring in sunflower seed hulls. The SSH-AM enriched in functional amine groups showed a significantly higher affinity to dyes than $\mathrm{SSH}$ did. At $\mathrm{pH}<7$, the $-\mathrm{NH}_{2}$ groups of the aminated polysaccharides were easily undergoing protonation 
Fig. 2 Effect of $\mathrm{pH}$ on dye sorption effectiveness: a RB5, b RY84, c AY23 and d AR18
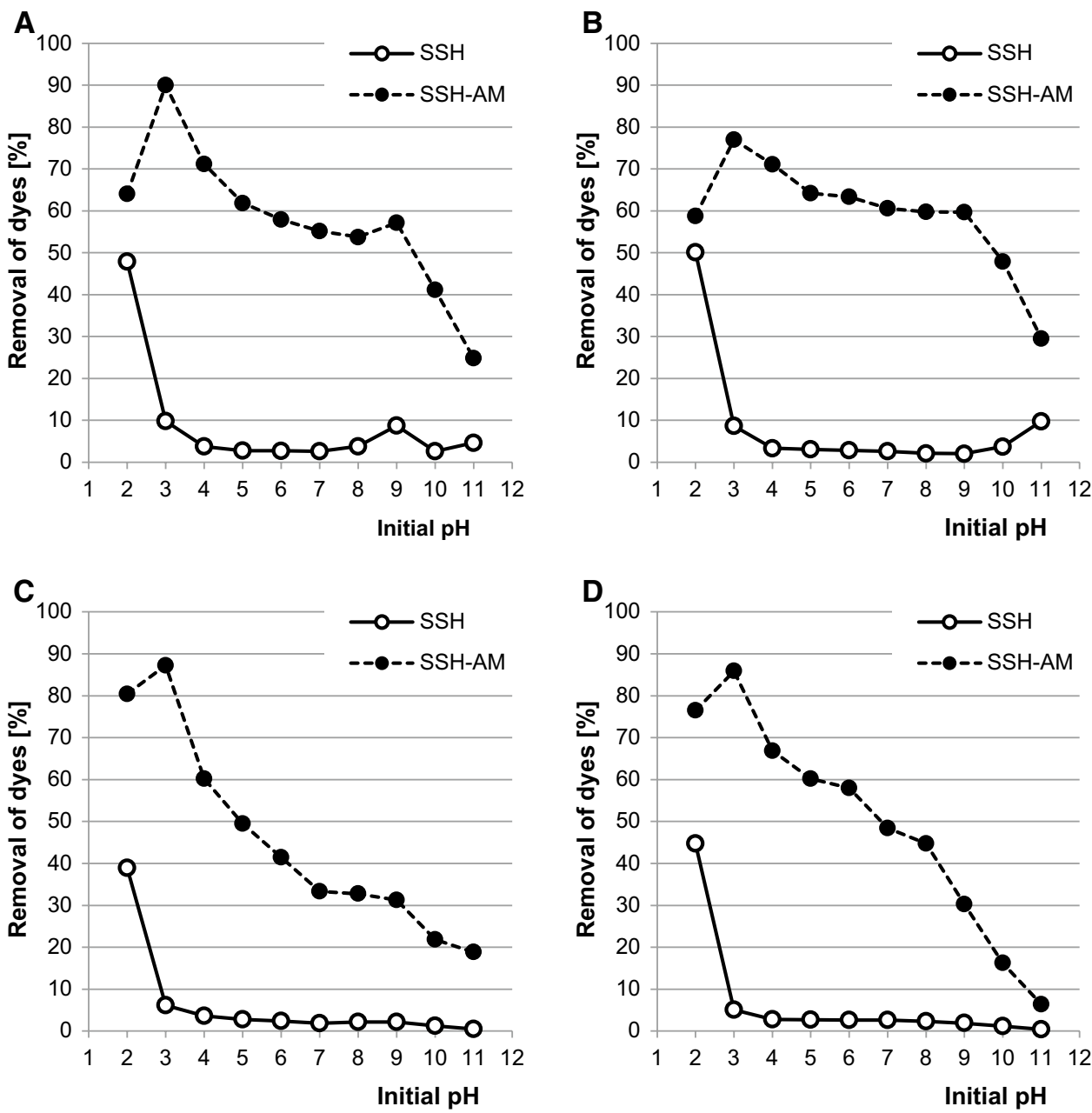

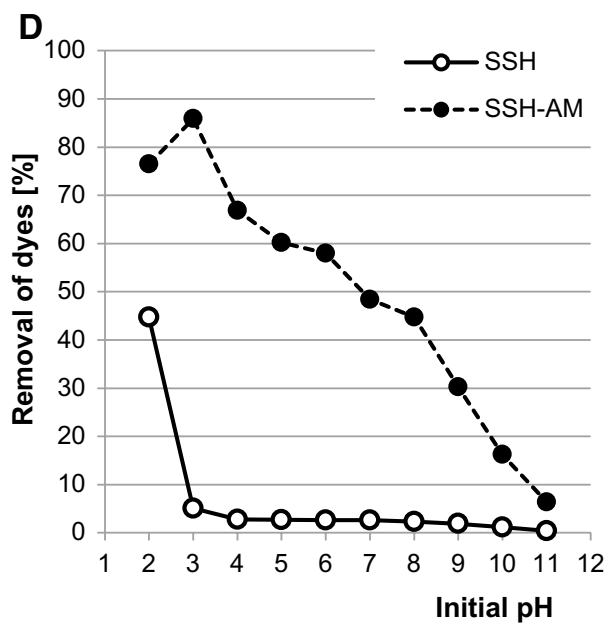

$\left(-\mathrm{NH}_{2}+\mathrm{H}_{3} \mathrm{O}^{+} \rightarrow-\mathrm{NH}_{3}{ }^{+}+\mathrm{H}_{2} \mathrm{O}\right)$. The positively charged functional groups were electrostatically attracting the anionic forms of dyes, which significantly enhanced their sorption. The number of protonated functional groups of SSH$\mathrm{AM}$ was increasing along with $\mathrm{pH}$ decrease, which explains the highest effectiveness of anionic dyes removal at low $\mathrm{pH}$ (Fig. 2). The lower dye sorption effectiveness at $\mathrm{pH} 2 \mathrm{com}-$ pared to $\mathrm{pH} 3$ may result from high competition of dyes with chlorides for the amine sorption centers (Sakkayawong et al. 2005).

At high $\mathrm{pH}$, both SSH and SSH-AM gained the negative charge. Sorption of anionic dyes was, therefore, inhibited by electrostatic repulsion from the negatively charged $\mathrm{SSH} /$ SSH-AM surface. The very low dye sorption effectiveness at high $\mathrm{pH}$ may also result from the competition of dyes with $\mathrm{OH}-$ ions for free sorption centers of SSH/SSH-AM. It was especially tangible in the case of acidic dyes sorption on the tested sorbents (Fig. 2c, d). The small increase in the effectiveness of reactive dyes removal on $\mathrm{SSH}$, noted at $\mathrm{pH}$ 11 (Fig. 2a, b), may be due to the chemisorption of reactive dyes as a result of condensation with SSH polysaccharides (Sakkayawong et al. 2005).
The small increase in RB5 sorption effectiveness observed at $\mathrm{pH} 9$ on both SSH and SSH-AM (Fig. 2a) was, probably, due to the presence of the amine group in dye structure. Presumably, at $\mathrm{pH} 9$ the surface of sorbents attained the total negative charge, while the amine group of RB5 still possessed the local positive charge $\left(-\mathrm{NH}_{3}{ }^{+}\right)$, which could aid dye sorption only to a little extent. At higher $\mathrm{pH}$, the functional amine group of dye lost its positive charge, which resulted in a significant decrease in RB5 sorption effectiveness.

Decreasing effectiveness of anionic dyes sorption along with $\mathrm{pH}$ increase was also observed in studies addressing sorption with the use of cotton stems (Tunç et al. 2009), maize silage (Filipkowska et al. 2013), chitosan materials (Jóźwiak et al. 2016, 2017a) and compost (Jóźwiak et al. 2013).

The tested sorbents changed the $\mathrm{pH}$ value of dye solution in which sorption proceeded (Fig. 3). At the initial pH 4-9, the final $\mathrm{pH}$ accounted for $\mathrm{pH}$ 7.0-7.6 during sorption onto SSH, and for 7.2-7.9 during sorption onto SSH-AM. The changes in $\mathrm{pH}$ values of the solutions resulted from system tending to reach $\mathrm{pH}$ close to the sorbent-specific 
Fig. $3 \mathrm{pH}$ values after dye sorption: a RB5, b RY84, c AY23, d AR18 and e determination of $\mathrm{pH}_{\mathrm{PZC}}$ values for $\mathrm{SSH}$ and SSH-AM
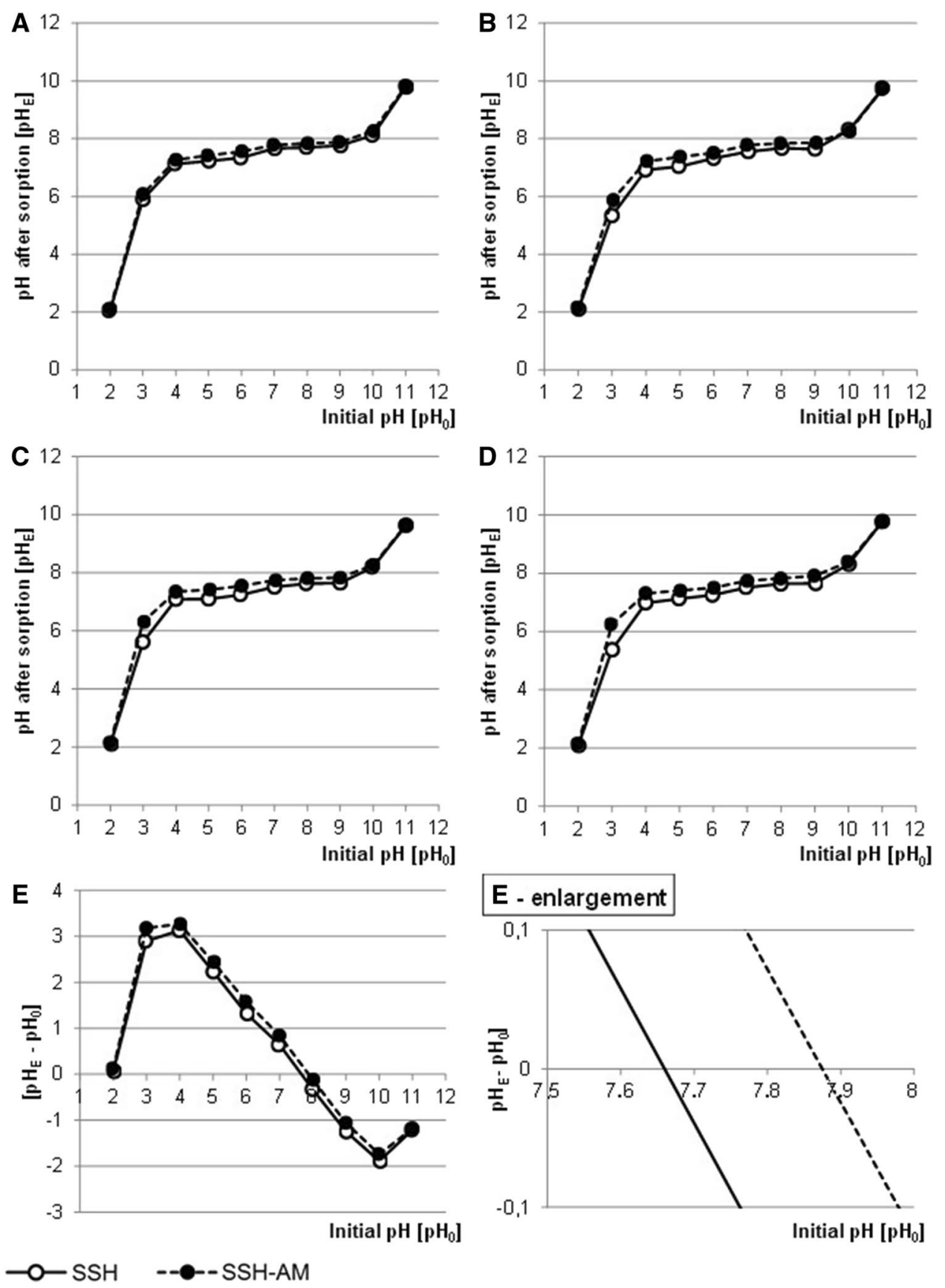

$\mathrm{pH}_{\mathrm{PZC}}$ value ( $\mathrm{PZC}$ - point of zero charge). The $\mathrm{pH}_{\mathrm{PZC}}$ value determined for $\mathrm{SSH}$ was 7.65 , and that determined for SSH-AM was 7.87 (Fig. 3e).

The higher $\mathrm{pH}_{\mathrm{PZC}}$ value determined for SSH-AM results from the effect of the amine groups attached to the sorbent on its base character. This is a direct proof of the amination of polysaccharides present in sunflower seed hulls.

For SSH, the best $\mathrm{pH}$ out of all tested $\mathrm{pH}$ values of anionic dyes sorption turned out to be $\mathrm{pH} 2$, while for SSH$\mathrm{AM}-\mathrm{pH}$ 3. Considering that $\mathrm{pH}$ of colored industrial wastewater is rarely below $\mathrm{pH} 3$, further analyses (sorption kinetics and capacity) were conducted at $\mathrm{pH} 3$.

\section{Analyses of sorption kinetics}

\section{Sorption equilibrium time}

Regardless of their initial concentration, the sorption equilibrium time on SSH reached 90 min for all tested dyes (Table 2). A similar time of reaching equilibrium was also 
Table 2 Times needed to reach dye sorption equilibrium on the tested sorbents together with $q_{\mathrm{e}}$ and $q / q_{\mathrm{e}}$ values for sorption times of $5 / 10 / 20 / 30 \mathrm{~min}$

\begin{tabular}{|c|c|c|c|c|c|c|c|c|c|c|c|c|c|}
\hline \multirow{2}{*}{$\frac{\text { Sorbent }}{\mathrm{SSH}}$} & \multirow[t]{2}{*}{ - } & \multicolumn{3}{|l|}{ RB5 } & \multicolumn{3}{|c|}{ RY84 } & \multicolumn{3}{|c|}{ AY23 } & \multicolumn{3}{|c|}{ AR18 } \\
\hline & & 10 & 50 & 250 & 10 & 50 & 250 & 10 & 50 & 250 & 10 & 50 & 250 \\
\hline & Equilibrium time (min) & 90 & 90 & 90 & 90 & 90 & 90 & 90 & 90 & 90 & 90 & 90 & 90 \\
\hline & $q_{\mathrm{e}}(\mathrm{mg} / \mathrm{g})$ & 0.44 & 0.98 & 2.01 & 0.49 & 0.92 & 2.45 & 0.20 & 0.61 & 1.41 & 0.20 & 0.53 & 1.26 \\
\hline & $q / q_{\mathrm{e}}(\%), t=5 \mathrm{~min}$ & 46 & 48 & 49 & 48 & 52 & 59 & 40 & 41 & 46 & 48 & 47 & 49 \\
\hline & $q / q_{\mathrm{e}}(\%), t=10 \min$ & 67 & 68 & 70 & 68 & 71 & 80 & 59 & 62 & 73 & 61 & 64 & 68 \\
\hline & $q / q_{\mathrm{e}}(\%), t=20 \mathrm{~min}$ & 80 & 81 & 84 & 78 & 81 & 92 & 75 & 76 & 85 & 74 & 77 & 81 \\
\hline & $q / q_{\mathrm{e}}(\%), t=30 \mathrm{~min}$ & 86 & 87 & 91 & 86 & 87 & 96 & 80 & 82 & 90 & 80 & 87 & 90 \\
\hline \multirow[t]{7}{*}{ SSH-AM } & Dye concentration $(\mathrm{mg} / \mathrm{L})$ & 50 & 250 & 500 & 50 & 250 & 500 & 50 & 250 & 500 & 50 & 250 & 500 \\
\hline & Equilibrium time (min) & 240 & 240 & 240 & 240 & 240 & 240 & 240 & 240 & 240 & 240 & 240 & 240 \\
\hline & $q_{\mathrm{e}}(\mathrm{mg} / \mathrm{g})$ & 9.87 & 44.86 & 52.66 & 9.06 & 39.70 & 53.02 & 9.91 & 40.28 & 48.17 & 9.93 & 39.97 & 46.14 \\
\hline & $q / q_{\mathrm{e}}(\%), t=5 \min$ & 79 & 39 & 38 & 67 & 41 & 40 & 48 & 38 & 37 & 67 & 45 & 44 \\
\hline & $q / q_{\mathrm{e}}(\%), t=10 \mathrm{~min}$ & 86 & 52 & 51 & 76 & 52 & 51 & 61 & 51 & 49 & 75 & 55 & 54 \\
\hline & $q / q_{\mathrm{e}}(\%), t=20 \mathrm{~min}$ & 90 & 65 & 64 & 83 & 66 & 61 & 71 & 62 & 58 & 82 & 66 & 64 \\
\hline & $q / q_{\mathrm{e}}(\%), t=30 \mathrm{~min}$ & 92 & 71 & 68 & 88 & 75 & 68 & 79 & 71 & 66 & 85 & 72 & 70 \\
\hline
\end{tabular}

noted in analyses of dye sorption on Parthenium hysterophorus biomass (90 $\mathrm{min}$ ) (Lata et al. 2007) and orange skin (80 min) (Sivaraj et al. 2001).

The effectiveness of anionic dyes sorption on SSH was the most intensive in the first stage of the process. Already within the first $20 \mathrm{~min}$, the quantity of RB sorbed on SSH ranged from 80 to $84 \%$ and that of RY 84 from 78 to $92 \%$ of the quantity of dye bound after the equilibrium time $\left(q_{\mathrm{e}}\right)$. In the case of the acidic dyes, the quantity of dye removed on SSH within the first 30 min was $75-85 \%$ and $74-81 \%$ of the $q_{\mathrm{e}}$ value for AY23 and AR18, respectively (Table 2).

In the case of SSH-AM, the time needed to reach sorption equilibrium was $240 \mathrm{~min}$ irrespective of dye type and concentration (Table 2). A similar sorption equilibrium time was achieved for carbonized date stones (180 min) (Belhamdi et al. 2016) and carbonized sawdust (180 min) (Malik 2003).

Likewise on SSH, dyes sorption on SSH-AM was the most intensive in the first minutes of the process. Within the first 20 min of the sorption process, the quantity of RB5 and RY84 bound on SSH-AM ranged from 61 to $90 \%$ of the $q_{\mathrm{e}}$ value. In the case of acidic dyes, after 20 min sorption on SSH-AMM, the quantity of sorbed AY 23 ranged from 58 to $71 \%$ of $q_{\mathrm{e}}$ and that of AR18 from 64 to $82 \%$ of $q_{\mathrm{e}}$ (Table 2).

The time needed to reach the equilibrium of dyes sorption on SSH-AM was significantly longer than on SSH, which probably results from different structures of the tested sorbents. Presumably, polysaccharides present in sunflower seed hulls (cellulose, hemicellulose) were enriched in amine groups during amination. The $-\mathrm{NH}_{2}$ groups attached to the polysaccharides and present on the surface of SSH-AM were protonated at low $\mathrm{pH}$. The positively charged chains of polysaccharides started to electrostatically repulse from each other, thereby loosening sorbent structure and by this means enlarging the surface and access to sorption centers located in deeper layers of the sorbent. During dyes sorption on SSH-AM, after filling up sorption centers on sorbent surface, the dyes penetrated the loosened polysaccharide structure of the sorbent and could bind with the active sites in its deeper layers.

Due to the high molecular weight of dyes, they penetrate underneath sorbent surface relatively slow. For this reason, the time needed to reach dye sorption equilibrium on SSHAM was considerably longer than on SSH. It may be speculated that owing to the compact structure of SSH, the dyes could not penetrate into the sorption centers in its deeper layers and their sorption terminated once they filled the active centers on sorbent surface. For this reason, dyes sorption equilibrium time on SSH was relatively short.

\section{Determination of the pseudo-order of sorption reaction}

Results obtained in the study were described using the pseudo-first-order and pseudo-second-order models (Fig. 4). In each case, better fit of experimental data was achieved with the pseudo-second-order model (Table 3).

The values of the reaction rate constant $k_{2}$ determined from this model depended mainly on sorbent type, but also on the initial concentration of dye. The $k_{2}$ values obtained for SSH were significantly higher than these calculated for SSH-AM. In each case, the value of $k_{2}$ constant decreased and that of Qe increased along with the increasing dye concentration (Table 3). This is indicative of the typically ionic interaction between the dye and the sorbent. A similar tendency was observed in analyses conducted on carbonized coconut shells (Tan et al. 2008), and on "rattan" type sawdust (Hameed et al. 2007). 
Fig. 4 Kinetics of sorption of dyes: a RB5 on SSH, b RB5 on SSH-AM, c RY84 on SSH, d RY84 on SSH-AM, e AY23 on SSH, $\mathbf{f}$ AY23 on SSH-AM, g AR18 on SSH and h AR18 on SSH-AM. Pseudo-firstorder and pseudo-second-order models
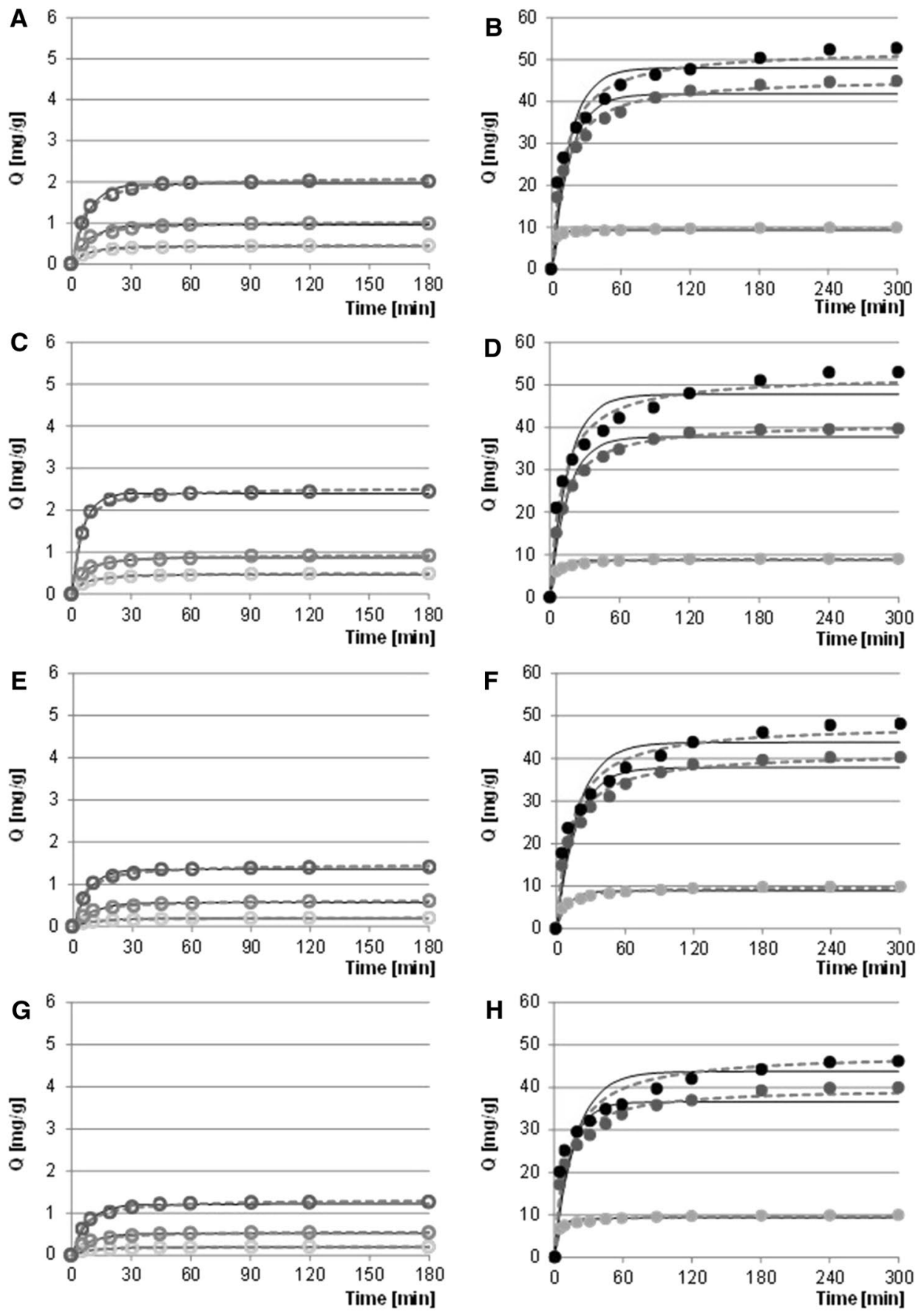

- $\quad 50 \mathrm{mg} / \mathrm{L}$
- $\quad 250 \mathrm{mg} / \mathrm{L}$ (SS/L
---- Pseudo-first order model
The intensity of anionic dyes sorption on SSH-AM was significantly higher than on SSH (Fig. 4). This may be due to the functional amine groups of SSH-AM which exhibit a substantially higher affinity to dyes compared to hydroxyl groups and constitute the main sorption center of anionic dyes (Annadurai et al. 2008).

Besides direct interactions with dyes, the $-\mathrm{NH}_{2}$ group capable of protonation could also affect sorbent structure.
In the base environment, the amine chains of polysaccharides of sunflower seed hulls gained the positive charge, which presumably caused their repulsion from each other and increased the distance between them. The loosening of sorbent structure probably contributed to the enlargement of its specific surface and increased accessibility to sorption centers. This would explain the differences between sorption properties of SSH and SSH-AM. 
Table 3 Kinetic parameters of dyes sorption on SSH and SSH-AM determined from the pseudo-first-order and pseudo-second-order models

\begin{tabular}{|c|c|c|c|c|c|c|c|c|c|}
\hline \multirow[t]{2}{*}{ Dye type } & \multirow[t]{2}{*}{ Sorbent type } & \multirow{2}{*}{$\begin{array}{l}\text { Dye concentra- } \\
\text { tion }(\mathrm{mg} / \mathrm{L})\end{array}$} & \multicolumn{3}{|c|}{ Pseudo-first-order model } & \multicolumn{3}{|c|}{ Pseudo-second-order model } & \multirow{2}{*}{$\begin{array}{l}\text { Exp. data } \\
q_{\mathrm{e}}, \exp \\
(\mathrm{mg} / \mathrm{g})\end{array}$} \\
\hline & & & $\begin{array}{l}k_{1} \\
(1 / \mathrm{min})\end{array}$ & $\begin{array}{l}q_{\mathrm{e}}, \mathrm{cal} \\
(\mathrm{mg} / \mathrm{g})\end{array}$ & $\begin{array}{l}R^{2} \\
-\end{array}$ & $\begin{array}{l}k_{2} \\
(\mathrm{~g} / \mathrm{mg} * \min )\end{array}$ & $\begin{array}{l}q_{\mathrm{e}}, \mathrm{cal} \\
(\mathrm{mg} / \mathrm{g})\end{array}$ & $\begin{array}{l}R^{2} \\
-\end{array}$ & \\
\hline \multirow[t]{6}{*}{ RB5 } & \multirow[t]{3}{*}{$\mathrm{SSH}$} & 10 & 0.1143 & 0.425 & 0.9853 & 0.3597 & 0.464 & 0.9989 & 0.443 \\
\hline & & 50 & 0.1141 & 0.952 & 0.9821 & 0.1627 & 1.038 & 0.9985 & 0.985 \\
\hline & & 250 & 0.1242 & 1.964 & 0.9908 & 0.0894 & 2.125 & 0.9977 & 2.009 \\
\hline & \multirow[t]{3}{*}{ SSH-AM } & 50 & 0.3399 & 9.317 & 0.9884 & 0.0832 & 9.616 & 0.9976 & 9.874 \\
\hline & & 250 & 0.0654 & 41.786 & 0.9462 & 0.0021 & 45.650 & 0.9915 & 44.861 \\
\hline & & 500 & 0.0653 & 48.044 & 0.9341 & 0.0018 & 52.558 & 0.9890 & 52.655 \\
\hline \multirow[t]{6}{*}{ RY84 } & \multirow[t]{3}{*}{ SSH } & 10 & 0.1209 & 0.464 & 0.9747 & 0.3498 & 0.506 & 0.9977 & 0.493 \\
\hline & & 50 & 0.1380 & 0.870 & 0.9757 & 0.2193 & 0.941 & 0.9976 & 0.921 \\
\hline & & 250 & 0.1769 & 2.396 & 0.9957 & 0.1208 & 2.537 & 0.9970 & 2.449 \\
\hline & \multirow[t]{3}{*}{ SSH-AM } & 50 & 0.1983 & 8.641 & 0.9625 & 0.0377 & 9.069 & 0.9941 & 9.062 \\
\hline & & 250 & 0.0665 & 37.765 & 0.9636 & 0.0024 & 41.135 & 0.9963 & 39.702 \\
\hline & & 500 & 0.0638 & 47.759 & 0.9091 & 0.0018 & 52.414 & 0.9743 & 53.022 \\
\hline \multirow[t]{6}{*}{ AY23 } & \multirow[t]{3}{*}{$\mathrm{SSH}$} & 10 & 0.0850 & 0.193 & 0.9763 & 0.5582 & 0.213 & 0.9979 & 0.201 \\
\hline & & 50 & 0.0996 & 0.567 & 0.9789 & 0.2223 & 0.626 & 0.9987 & 0.607 \\
\hline & & 250 & 0.1283 & 1.365 & 0.9919 & 0.1307 & 1.478 & 0.9945 & 1.412 \\
\hline & \multirow[t]{3}{*}{ SSH-AM } & 50 & 0.1116 & 8.869 & 0.9512 & 0.0162 & 9.739 & 0.9915 & 9.906 \\
\hline & & 250 & 0.0586 & 37.850 & 0.9465 & 0.0021 & 41.430 & 0.9902 & 40.283 \\
\hline & & 500 & 0.0540 & 43.772 & 0.9154 & 0.0016 & 48.164 & 0.9779 & 48.171 \\
\hline \multirow[t]{6}{*}{ AR18 } & \multirow[t]{3}{*}{ SSH } & 10 & 0.0959 & 0.189 & 0.9537 & 0.6693 & 0.207 & 0.9905 & 0.198 \\
\hline & & 50 & 0.1037 & 0.517 & 0.9808 & 0.2709 & 0.565 & 0.9976 & 0.532 \\
\hline & & 250 & 0.1188 & 1.224 & 0.9873 & 0.1361 & 1.327 & 0.9981 & 1.263 \\
\hline & \multirow[t]{3}{*}{ SSH-AM } & 50 & 0.2045 & 9.294 & 0.9539 & 0.0384 & 9.643 & 0.9915 & 9.931 \\
\hline & & 250 & 0.0764 & 36.581 & 0.9274 & 0.0028 & 39.847 & 0.9844 & 39.967 \\
\hline & & 500 & 0.0779 & 41.073 & 0.8980 & 0.0025 & 44.927 & 0.9692 & 46.138 \\
\hline
\end{tabular}

\section{Determination of the duration of particular stages of sorption process}

The intramolecular diffusion model fitted to experimental data indicates that sorption of dyes on SSH and SSH-AM proceeded in two main stages (Table 4).

At the first stage, the dyes bound with easily accessible sorption centers are located on sorbent surface. This stage was relatively short and highly intensive. In the second stage, dyes have diffused through the pores to the active centers located in the deeper sorbent layers. Difficulties in the penetration of dyes through the porous structure of sorbent, as well high accumulation of dyes on sorbent surface and interactions between dyes resulted in a relatively long time of the second stage of sorption and its lesser intensity.

In the case of SSH-AM, the sorption process still continued after stage 2 until reaction equilibrium has been reached; however, its intensity was very low. Presumably, in this period a few molecules of dyes were attaching to the last free sorption centers of SSH-AM located in earlier unavailable regions of the sorbent. Due to a small quantity of dye sorbed in this time $\left(<1 \% q_{\mathrm{e}}\right)$, and to the very poor fit of data to the intramolecular diffusion model $\left(R^{2}<0.6\right)$, this period was not classified as a significant stage of the sorption reaction. For this reason, this period is not considered in Table 4.

Regardless of the type and initial concentration of dye $(10-250 \mathrm{mg} / \mathrm{L})$, the first stage of anionic dyes sorption on SSH lasted $10 \mathrm{~min}$, while the second one $-80 \mathrm{~min}$ (Table 4). In the case of SSH-AM, the first stage of sorption depended on the initial concentration of dye. At the initial dye concentration of $50 \mathrm{mg} / \mathrm{L}$, the first stage ended after $5 \mathrm{~min}$, while at higher concentrations $(250 / 500 \mathrm{mg} / \mathrm{L})$ after $10 \mathrm{~min}$. The likely reason of the shorter first stage at the initial dye concentration of $50 \mathrm{mg} / \mathrm{L}$ was a very high ratio of easily available sorption centers on sorbent surface to sorbate molecules in the solution.

The ammonization process contributed to the elongation of the second stage of sorption as a result of changes in sorbent structure. The reason behind the longer duration of dyes sorption on SSH-AM was described in point "Sorption equilibrium time". 
Table 4 Dye diffusion rate constants determined from a simplified model of intramolecular diffusion

\begin{tabular}{|c|c|c|c|c|c|c|c|c|}
\hline \multirow[t]{2}{*}{ Dye } & \multirow[t]{2}{*}{ Sorbent } & \multirow{2}{*}{$\begin{array}{l}\text { Dye conc. } \\
\mathrm{mg} / \mathrm{L}\end{array}$} & \multicolumn{3}{|c|}{ First stage of sorption } & \multicolumn{3}{|c|}{ Second stage of sorption } \\
\hline & & & $\begin{array}{l}k_{d 1} \\
\left(\mathrm{mg} /\left(\mathrm{g}^{*} \min ^{0.5}\right)\right)\end{array}$ & $\begin{array}{l}\text { Duration } \\
\text { (min) }\end{array}$ & $\begin{array}{l}R^{2} \\
-\end{array}$ & $\begin{array}{l}k_{d 2} \\
\left(\mathrm{mg} /\left(\mathrm{g}^{*} \min ^{0.5}\right)\right)\end{array}$ & $\begin{array}{l}\text { Duration } \\
\text { (min) }\end{array}$ & $\begin{array}{l}R^{2} \\
-\end{array}$ \\
\hline \multirow[t]{6}{*}{ RB5 } & \multirow[t]{3}{*}{ SSH } & 10 & 0.0930 & $\sim 10$ & 0.9997 & 0.0196 & $\sim 80$ & 0.9996 \\
\hline & & 50 & 0.2104 & $\sim 10$ & 0.9999 & 0.0534 & $\sim 80$ & 0.9743 \\
\hline & & 250 & 0.4443 & $\sim 10$ & 0.9999 & 0.0903 & $\sim 80$ & 0.9407 \\
\hline & \multirow[t]{3}{*}{ SSH-AM } & 50 & 3.4887 & $\sim 5$ & 0.9999 & 0.1347 & $\sim 115$ & 0.9502 \\
\hline & & 250 & 7.4707 & $\sim 10$ & 0.9994 & 2.0842 & $\sim 110$ & 0.9689 \\
\hline & & 500 & 8.5664 & $\sim 10$ & 0.9947 & 2.2313 & $\sim 110$ & 0.9441 \\
\hline \multirow[t]{6}{*}{ RY84 } & \multirow[t]{3}{*}{ SSH } & 10 & 0.1059 & $\sim 10$ & 0.9999 & 0.0222 & $\sim 80$ & 0.8861 \\
\hline & & 50 & 0.2080 & $\sim 10$ & 0.9993 & 0.0326 & $\sim 80$ & 0.9326 \\
\hline & & 250 & 0.6262 & $\sim 10$ & 0.9989 & 0.0417 & $\sim 80$ & 0.8257 \\
\hline & \multirow[t]{3}{*}{ SSH-AM } & 50 & 2.7062 & $\sim 5$ & 0.9999 & 0.3144 & $\sim 115$ & 0.9510 \\
\hline & & 250 & 6.6134 & $\sim 10$ & 0.9994 & 1.5801 & $\sim 110$ & 0.9546 \\
\hline & & 500 & 8.7637 & $\sim 10$ & 0.9952 & 2.3259 & $\sim 110$ & 0.9812 \\
\hline \multirow[t]{6}{*}{ AY23 } & \multirow[t]{3}{*}{ SSH } & 10 & 0.0373 & $\sim 10$ & 0.9994 & 0.0134 & $\sim 80$ & 0.9924 \\
\hline & & 50 & 0.1181 & $\sim 10$ & 0.9972 & 0.0290 & $\sim 80$ & 0.9748 \\
\hline & & 250 & 0.3195 & $\sim 10$ & 0.9941 & 0.0528 & $\sim 80$ & 0.9366 \\
\hline & \multirow[t]{3}{*}{ SSH-AM } & 50 & 1.9394 & $\sim 10$ & 0.9928 & 0.3038 & $\sim 110$ & 0.9911 \\
\hline & & 250 & 6.4884 & $\sim 10$ & 0.9994 & 1.8575 & $\sim 110$ & 0.9800 \\
\hline & & 500 & 7.5603 & $\sim 10$ & 0.9978 & 2.1909 & $\sim 110$ & 0.9903 \\
\hline \multirow[t]{6}{*}{ AR18 } & \multirow[t]{3}{*}{ SSH } & 10 & 0.0389 & $\sim 10$ & 0.9923 & 0.0136 & $\sim 80$ & 0.9962 \\
\hline & & 50 & 0.1088 & $\sim 10$ & 0.9997 & 0.0332 & $\sim 80$ & 0.9596 \\
\hline & & 250 & 0.2713 & $\sim 10$ & 0.9995 & 0.0635 & $\sim 80$ & 0.9039 \\
\hline & \multirow[t]{3}{*}{ SSH-AM } & 50 & 2.9712 & $\sim 5$ & 0.9999 & 0.2354 & $\sim 115$ & 0.9485 \\
\hline & & 250 & 7.0656 & $\sim 10$ & 0.9939 & 1.6455 & $\sim 110$ & 0.9631 \\
\hline & & 500 & 8.1362 & $\sim 10$ & 0.9905 & 1.8952 & $\sim 110$ & 0.9918 \\
\hline
\end{tabular}

The $k_{d 1}$ and $k_{d 2}$ constants determined for the tested sorbents from the intramolecular diffusion model indicate higher intensity of stages 1 and 2 of sorption on SSH-AM than on SSH (Table 4). This results from higher affinity of the dyes to amine than to hydroxyl groups and also, presumably, from a greater active surface of SSH-AM compared to $\mathrm{SSH}$.

\section{Sorption capacity}

Experimental data obtained in the study were described with the use of two popular sorption isotherms (Langmuir isotherm and Freundlich isotherm). In each case, the greatest fit of experimental data was achieved with the Langmuir model (Table 5).
Table 5 Constants determined from Langmuir and Freundlich models

\begin{tabular}{|c|c|c|c|c|c|c|c|}
\hline \multirow[t]{3}{*}{ Sorbent } & \multirow[t]{3}{*}{ Dye } & \multicolumn{3}{|c|}{ Langmuir (constants) } & \multicolumn{3}{|c|}{ Freundlich (constants) } \\
\hline & & $q_{\max }$ & $K_{\mathrm{c}}$ & $R^{2}$ & $\vec{k}$ & $n$ & $R^{2}$ \\
\hline & & $(\mathrm{mg} / \mathrm{g})$ & $(\mathrm{L} / \mathrm{mg})$ & - & - & - & - \\
\hline \multirow[t]{4}{*}{ SSH } & RB5 & 2.89 & 0.0116 & 0.9720 & 0.2425 & 0.3888 & 0.9654 \\
\hline & RY84 & 4.15 & 0.0067 & 0.9723 & 0.1829 & 0.4718 & 0.9517 \\
\hline & AY23 & 2.26 & 0.0071 & 0.9838 & 0.1032 & 0.4699 & 0.9780 \\
\hline & AR18 & 1.77 & 0.0089 & 0.9930 & 0.1056 & 0.4353 & 0.9629 \\
\hline \multirow[t]{4}{*}{ SSH-AM } & RB5 & 51.02 & 0.3740 & 0.9817 & 17.1397 & 0.2310 & 0.8219 \\
\hline & RY84 & 63.27 & 0.0296 & 0.9958 & 6.4758 & 0.4112 & 0.9119 \\
\hline & AY23 & 44.78 & 0.2468 & 0.9576 & 13.9969 & 0.2451 & 0.9218 \\
\hline & AR18 & 42.19 & 0.4809 & 0.9662 & 14.8656 & 0.2258 & 0.8975 \\
\hline
\end{tabular}


Table 6 Sorption capacities of selected sorbents produced from waste materials and of sorbents based on activated carbons against RB5, RY84, AY23 and AR18 dyes

\begin{tabular}{|c|c|c|c|c|c|}
\hline Dye & Sorbent & $\begin{array}{l}\text { Sorption capacity } \\
\left(q_{\max }\right)(\mathrm{mg} / \mathrm{g})\end{array}$ & $\begin{array}{l}\text { Sorpt. time } \\
(\mathrm{min})\end{array}$ & $\mathrm{pH}$ & Source \\
\hline \multirow[t]{10}{*}{ RB5 } & Activated carbon modified with surfactant & 69.9 & $<60$ & 2 & Nabil et al. (2014) \\
\hline & Powdered activated carbon & 58.8 & - & - & Eren and Acar (2006) \\
\hline & Aminated sunflower seed hulls (SSH-AM) & 51.0 & 240 & 3 & Own study \\
\hline & Cotton stems (plant waste) & 35.7 & 360 & 1 & Tunç et al. (2009) \\
\hline & Activated carbon from wood (nut tree) & 19.3 & 400 & 5 & Heibati et al. (2014) \\
\hline & Wheat straw & 15.7 & 195 & 7 & Yousefi et al. (2011) \\
\hline & Cotton seed hulls & 12.9 & 30 & 2 & Uçar and Armağan (2012) \\
\hline & Compost & 4.8 & 120 & 3 & Jóźwiak et al. (2013) \\
\hline & Sunflower seed hulls (SSH) & 2.9 & 90 & 3 & Own study \\
\hline & Sunflower seed hulls & 1.1 & 210 & 2 & Osma et al. (2007) \\
\hline \multirow[t]{4}{*}{ RY84 } & Aminated sunflower seed hulls (SSH-AM) & 63.3 & 240 & 3 & Own study \\
\hline & Wool & 11.0 & 180 & 7 & Sahin (2005) \\
\hline & Sunflower seed hulls (SSH) & 4.2 & 90 & 3 & Own study \\
\hline & Compost & 2.2 & 180 & 3 & Jóźwiak et al. (2013) \\
\hline \multirow[t]{6}{*}{ AY23 } & Aminated sunflower seed hulls (SSH-AM) & 44.8 & 240 & 3 & Own study \\
\hline & Chitin & 24.2 & 120 & 2 & Filipkowska et al. (2015) \\
\hline & Sawdust & 4.7 & 70 & 3 & Banerjee and Chattopadhyaya (2017) \\
\hline & Sunflower seed hulls (SSH) & 2.3 & 90 & 3 & Own study \\
\hline & Coconut shell activated carbon & 2.3 & 60 & 1.7 & Jibril et al. (2013) \\
\hline & Commercial activated carbon & 4.5 & 60 & 1.7 & Jibril et al. (2013) \\
\hline \multirow[t]{5}{*}{ AR18 } & Activated carbon WG-12 & 100.0 & - & - & Okoniewska (2016) \\
\hline & Aminated sunflower seed hulls (SSH-AM) & 42.2 & 240 & 3 & Own study \\
\hline & Sargassum glaucescens biomass & 15.0 & 60 & 6 & Zazouli and Moradi (2015) \\
\hline & Activated carbon from wood (polar tree) & 3.9 & 120 & 7 & Shokoohi et al. (2010) \\
\hline & Sunflower seed hulls (SSH) & 1.8 & 90 & 3 & Own study \\
\hline
\end{tabular}

The maximum sorption capacity of SSH against reactive dyes reached: $2.89 \mathrm{mg} \mathrm{RB5/g}$ and $4.15 \mathrm{mg} \mathrm{RY} 84 / \mathrm{g}$, whereas against acidic dyes-2.26 mg AY23/g and $1.77 \mathrm{mg} \mathrm{AR18/g}$ (Table 5). In turn, the sorption capacity of SSH-AM against reactive dyes RB5 and RY84 accounted for $51.02 \mathrm{mg} / \mathrm{g}$ and $63.27 \mathrm{mg} / \mathrm{g}$, respectively, and was higher by $1665 \%$ and $1425 \%$ compared to that of SSH. In the case of acidic dyes, the sorption capacity of SSH-AM reached $44.78 \mathrm{mg} / \mathrm{g}$ (AY23) and $42.19 \mathrm{mg} / \mathrm{g}$ (AR18) and was higher by $1881 \%$ and $2284 \%$, respectively, compared to SSH (Table 5).

The SSH-AM sorbent was also characterized by significantly higher values of $K_{\mathrm{c}}$ constant compared to SSH, which was indicative of a higher affinity of the aminated sorbent to anionic dyes compared to the non-modified sorbent. High values of $K_{\mathrm{c}}$ are constant points to high sorption effectiveness even at very low concentrations of the sorbate.

The higher sorption capacity and higher affinity to dyes of the SSH-AM sorbent compared to SSH results from the amination process of sunflower seed hulls. As mentioned in point "Effect of $\mathrm{pH}$ on dye sorption effectiveness", during ammonization, the polysaccharides present in sunflower seed hulls underwent amination consisting in the attachment of amine groups to their chemical structure. Capable of protonation amine groups of SSH-AM exhibited a significantly higher affinity to anionic dyes than the hydroxyl groups of SSH. The ammonization presumably resulted also in the enlargement of surface sorbent and in the loosening of its structure. The mechanism of loosening of a compact structure of a sunflower seed hull, resulting in greater availability of sorption centers, was described in detail in point "Analyses of sorption kinetics".

The greater capability of the tested sorbents for the sorption of reactive than acidic dyes (Table 5) could result from the capability of reactive dyes for chemisorption and from their higher molecular weight.

Table 6 presents values of sorption capacity of exemplary sorbents produced from waste materials from the agri-food industry and also of sorbents based on activated carbons against the tested dyes. After amination, the sunflower seed hulls gained a higher sorption capacity compared to such non-modified lignocellulosic sorbents as: straw, cotton seed hulls, rape stems or sawdust (Table 6). The SSH-AM sorbent 
showed sorption properties against anionic dyes similar to that of some sorbents based on activated carbons (Table 6).

\section{Conclusion}

Modification of SSH, consisting in their ammonization (preceded by activation using epichlorohydrin), contributes to a significant increase in their sorption capacity against anionic dyes. This is due to the amination of polysaccharides of sunflower seed hull. The amine groups introduced into the sorbent are sorption centers for anionic dyes. The SSH-AM sorbent is capable of binding some dyes with the effectiveness similar to that of activated carbons. Compared to SSH, the SSH-AM is characterized also by a higher coefficient of affinity to dyes $\left(K_{\mathrm{c}}\right)$, which points to a higher effectiveness of sorption on SSH-AM even at very low concentrations of dyes.

Acknowledgements This study was financed under Project No. 18.610.008-300 of the University of Warmia and Mazury in Olsztyn, Poland.

Open Access This article is distributed under the terms of the Creative Commons Attribution 4.0 International License (http://creativeco mmons.org/licenses/by/4.0/), which permits unrestricted use, distribution, and reproduction in any medium, provided you give appropriate credit to the original author(s) and the source, provide a link to the Creative Commons license, and indicate if changes were made.

\section{References}

Abdollah MR, Kalber T, Tolner B, Southern P, Bear JC, Robson M, Pedley RB, Parkin IP, Pankhurst QA, Mulholland P, Chester K (2014) Prolonging the circulatory retention of SPIONs using dextran sulfate: in vivo tracking achieved by functionalisation with near-infrared dyes. Faraday Discuss 175:41-58

Annadurai G, Ling LY, Lee JF (2008) Adsorption of reactive dye from an aqueous solution by chitosan: isotherm kinetic and thermodynamic analysis. J Hazard Mater 152:337-346

Arami M, Limaee NY, Mahmoodi NM, Tabrizi NS (2005) Removal of dyes from colored textile wastewater by orange peel adsorbent: equilibrium and kinetic studies. J Colloid Interface Sci 288:371-376

Banerjee S, Chattopadhyaya MC (2017) Adsorption characteristics for the removal of a toxic dye tartrazine from aqueous solutions by a low cost agricultural by-product. Arab J Chem 10:1629-1638

Belhamdi B, Merzougui Z, Trari M, Addoun A (2016) A kinetic equilibrium and thermodynamic study of L-phenylalanine adsorption using activated carbon based on agricultural waste (date stones). J Appl Res Technol 14:354-366

Çelekli A, Çelekli F, Çiçek E, Bozkurt H (2014) Predictive modeling of sorption and desorption of a reactive azo dye by pumpkin husk. Environ Sci Pollut Res Int 21:5086-5097

Crini G (2006) Non-conventional low-cost adsorbents for dye removal: a review. Bioresource Technol 97:1061-1085

Dulman V, Cucu-Man SM (2009) Sorption of some textile dyes by beech wood sawdust. J Hazard Mater 162:1457-1464
Eren Z, Acar FN (2006) Adsorption of Reactive Black 5 from an aqueous solution: equilibrium and kinetic studies. Desalination 194:1-10

Fan M, Dai D, Huang B (2012) Fourier transform infrared spectroscopy for natural fibres. Fourier Transf Mater Anal 3:46-68

Filipkowska U, Jóźwiak T, Rodziewicz J, Kuciejewska J (2013) Application of maize silage as a biosorbent for the removal of dyes from aqueous solutions. Rocz Ochr Sr 15:2324-2338

Filipkowska U, Kuczajowska-Zadrożna M, Jóźwiak T, Szymczyk P, Kaczyński A (2015) Adsorption of basic yellow 28 (BY28) and acid yellow 23 (AY23) dyes onto chitin. Prog Chem Appl Chitin Deriv 20:34-42

Gupta VK, Suhas (2009) Application of low-cost adsorbents for dye removal-a review. J Environ Manage 90:2313-2342

Hameed BH, Ahmad AL, Latiff KNA (2007) Adsorption of basic dye (methylene blue) onto activated carbon prepared from rattan sawdust. Dyes Pigments 75:143-149

Heibati B, Rodriguez-Couto S, Amrane A, Rafatullah M, Hawari A, Al-Ghouti MA (2014) Uptake of Reactive Black 5 by pumice and walnut activated carbon: chemistry and adsorption mechanisms. J Ind Eng Chem 20:2939-2947

Jibril M, Noraini J, Poh LS, Evuti AM (2013) Removal of color from waste water using coconut shell activated carbon (CSAC) and commercial activated carbon (CAC). J Teknol 60:15-19

Jóźwiak T, Filipkowska U, Rodziewicz J, Kuciejewska J (2013) Application of compost as a cheap sorbent for dyes removal from aqueous solutions. Rocz Ochr Sr 15:2324-2338

Jóźwiak T, Filipkowska U, Szymczyk P, Kuczajowska-Zadrożna M, Mielcarek A (2015) Application of chitosan ionically crosslinked with sodium edetate for reactive dyes removal from aqueous solutions. Prog Chem Appl Chitin Deriv 20:82-96

Jóźwiak T, Filipkowska U, Szymczyk P, Kuczajowska-Zadrożna M, Mielcarek A, Zyśk M (2016) The influence of chitosan deacetylation degree on reactive black 5 sorption efficiency from aqueous solutions. Prog Chem Appl Chitin Deriv 21:83-92

Jóźwiak T, Filipkowska U, Szymczyk P, Rodziewicz J, Mielcarek A (2017a) Effect of ionic and covalent crosslinking agents on properties of chitosan beads and sorption effectiveness of Reactive Black 5 dye. React Funct Polym 114:58-74

Jóźwiak T, Filipkowska U, Szymczyk P, Zyśk M (2017b) Effect of the form and deacetylation degree of chitosan sorbents on sorption effectiveness of Reactive Black 5 from aqueous solutions. Int J Biol Macromol 95:1169-1178

Lairini S, El Mahtal K, Miyah Y, Tanji K, Guissi S, Boumchita S, Zerrouq F (2017) The adsorption of Crystal violet from aqueous solution by using potato peels (Solanum tuberosum): equilibrium and kinetic studies. J Mater Environ Sci 8:3252-3261

Lata H, Garg VK, Gupta RK (2007) Removal of a basic dye from aqueous solution by adsorption using Parthenium hysterophorus: an agricultural waste. Dyes Pigments 74:653-658

Lewis DM (1999) Coloration in the next century. Color Technol 29:23-28

Liu X, Zhu H, Qin C, Zhou J, Zhao JR, Wang S (2013) Adsorption of heavy metal ion from aqueous single metal solution by aminated epoxy-Lignin. BioResources 8:2257-2269

Mafra MR, Igarashi-Mafra L, Zuim DR, Vasques ÉC, Ferreira MA (2013) Adsorption of remazol brilliant blue on an orange peel adsorbent. Braz J Chem Eng 30:657-665

Malik PK (2003) Use of activated carbons prepared from sawdust and rice-husk for adsorption of acid dyes: a case study of Acid Yellow 36. Dyes Pigments 56:239-249

Nabil GM, El-Mallah NM, Mahmoud ME (2014) Enhanced decolorization of reactive black 5 dye by active carbon sorbent-immobilizedcationic surfactant (AC-CS). J Ind Eng Chem 20:994-1002 
Okoniewska E (2016) Removal of the dye of acid bright red 4R from water solutions on activated carbons. Inż Ochr Środow 19:331-340

Osma JF, Saravia V, Toca-Herrera JL, Couto SC (2007) Sunflower seed shells: a novel and effective low-cost adsorbent for the removal of the diazo dye Reactive Black 5 from aqueous solutions. J Hazard Mater 147:900-905

Papić S, Koprivanac N, Božić AL, Meteš A (2004) Removal of some reactive dyes from synthetic wastewater by combined Al(III) coagulation/carbon adsorption process. Dyes Pigments 62:291-298

Ponnusamy SK, Subramaniam R (2013) Process optimization studies of Congo red dye adsorption onto cashew nut shell using response surface methodology. Int J Ind Chem 4:1-10

Ratnamala GM, Deshannavar UB, Munyal S, Tashildar K, Patil S, Shinde A (2016) Adsorption of reactive blue dye from aqueous solutions using sawdust as adsorbent: optimization kinetic and equilibrium studies. Arab J Sci Eng 41:333-344

Razavi N, Akhlaghinia B (2015) Cu(II) immobilized on aminated epichlorohydrin activated silica (CAES): as a new green and efficient nanocatalyst for preparation of 5-substituted-1H-tetrazoles. RSC Adv 5:12372-12381

Revankar MS, Lele SS (2007) Synthetic dye decolorization by white rot fungus Ganoderma sp WR-1. Bioresour Technol 98:775-780

Sahin E (2005) Interpretation of sorption kinetics for mixtures of reactive dyes on wool. Turk J Chem 29:617-625

Sakkayawong N, Thiravetyan P, Nakbanpote W (2005) Adsorption mechanism of synthetic reactive dye wastewater by chitosan. $\mathrm{J}$ Colloid Interface Sci 286:36-42

Saura-Calixto F, Cafiellas J, Garcia-Raso J (1983) Determination of hemieellulose cellulose and lignin contents of dietary fibre and crude fibre of several seed hulls data comparison. Z Lebensm Unters Forsch 177:200-202
Shokoohi R, Vatanpoor V, Zarrabi M, Vatani A (2010) Adsorption of acid red 18 (AR18) by activated carbon from poplar wood-a kinetic and equilibrium study. E-J Chem 7:65-72

Sivaraj R, Namasivayam C, Kadirvelu K (2001) Orange peel as an adsorbent in the removal of Acid violet 17 (acid dye) from aqueous solutions. Waste Manag 21:105-110

Subbaiah MV, Kim DS (2016) Adsorption of methyl orange from aqueous solution by aminated pumpkin seed powder: kinetics isotherms and thermodynamic studies. Ecotoxicol Environ Saf 128:109-117

Tan IAW, Ahmad AL, Hameed BH (2008) Adsorption of basic dye on high-surface-area activated carbon prepared from coconut husk: equilibrium kinetic and thermodynamic studies. J Hazard Mater 154:337-346

Tiwari DP, Singh SK, Sharma N (2015) Sorption of methylene blue on treated agricultural adsorbents: equilibrium and kinetic studies. Appl Water Sci 5:81-88

Tunç O, Tanacı H, Aksu Z (2009) Potential use of cotton plant wastes for the removal of Remazol Black B reactive dye. J Hazard Mater 163:187-198

Uçar D, Armağan B (2012) The removal of reactive black 5 from aqueous solutions by cotton seed shell. Water Environ Res 84:323-327

Yousefi N, Fatehizadeh A, Azizi E, Ahmadian M, Ahmadi A, Rajabizadeh A, Toolabi A (2011) Adsorption of reactive black 5 dye onto modified wheat straw: isotherm and kinetics study. Sacha $\mathbf{J}$ Environ Stud 1:81-91

Zazouli MA, Moradi E (2015) Adsorption Acid Red18 dye using Sargassum glaucescens biomass from aqueous solutions. Iran J Health Sci 3:7-13 